\title{
The Weaknesses of the Albanian Banking System
}

\author{
PhD student, Rudina Qurku (Feruni)
}

Lecturer at the Mediterranean University of Tirana. rudinaqurku@yahoo.com

Prof. In. Alqi Naqellari

Lecturer at the Mediterranean University of Tirana. alqinaqellari@gmail.com

\section{Doi:10.5901/mjss.2014.v5n4p87}

\section{Abstract}

\begin{abstract}
Albania has inherited a one-tier centralized banking system from the socialist system. A Central Bank that had under its control two other banks: the National Commercial Bank and the Agricultural Commercial Bank. These banks had subsidiaries and branches throughout Albania. The monetary policies of this system were based on the application of direct monetary instruments such as loan limits, the deposits lower margin interest rates and the loans higher margin interest rate. The foreign currency was a monopoly of the Central Bank. After the '90s, the two-tier banking system was established in Albania. The Central Bank of Albania that was established had as its main objective "to achieve and maintain the price stability". A number of commercial banks of the second-tier were established. The National Commercial Bank and the Savings Bank having entirely state-owned capital were privatized. The free movement of the Euro and the USD was allowed. Second-tier banks were allowed to accept deposits and to grant loans in foreign currency. The free movement of capital was allowed. Direct instruments were eliminated and indirect instruments were applied. The purpose of this study is to analyze the consequences of the change on the banking system, the transition from a centralized system to a two-tier banking system. The impact of the change in the areas of: economic growth, unemployment rate, inflation control, monetary base control, interest rates control in view of the dynamics of deposits and loans in Albanian Lek ("ALL"), exchange rate of the national currency, circulation of the national and foreign currency, role of national currency in the economic growth etc. By analyzing the above mentioned areas, we can determine the weaknesses of the new banking system established after the '90s as well as to express our views in relation to the ways and means to overcome this situation.
\end{abstract}

Keywords: Bank of Albania, inflation, exchange rate, money supply etc.

\section{Bank of Albania, a Bank of the European Model having per Objective: 'To Achieve and Maintain the Price Stability'}

Before 1990 and until 1997 the inherited one-tier banking system has existed, where the Bank of Albania had under its control two other banks the National Commercial Bank and the Agricultural Commercial Bank. The capital of these banks was entirely state-owned. The monetary policies of this system were based on the application of direct monetary instruments such as loan limits, the deposits lowest margin interest rate and the loans highest margin interest rate. Direct instruments were applied due to the absence of second-tier commercial banks with privately-owned capital.

After 1997, there were established commercial banks with private capital. In 1997 the Albanian Parliament approved the Law No. 8269, dated 23.12.1997, "On the Bank of Albania"1. This law clearly determined the separation of the banking system into two tiers. In the first tier the Bank of Albania or the Central Bank was included, whereas commercial banks were included in the second tier.

The transition into the two-tier banking system and the opening of commercial banks with entirely private-owned capital also dictated the transition to the implementation of indirect monetary instruments such as: open market operations, required reserve ratio and the base rate (the rate of repurchase agreement or REPO).

The comparison of the Objective of the Bank of Albania and its responsibilities will be carried out with the Objective and the responsibilities of the European Central Bank. This is due to the fact that Albania realizes over $60 \%$ of

${ }^{1}$ Law No.8269, dated 23.12.1997, the Bank of Albania. National Assembly. Tirana 
its export-import with the Euro zone member countries. Due to this ratio Euro zone member countries have a direct effect on the performance of the Albanian economy.

By comparing the main and the additional objectives of the two central banks, we can easily observe that they share the same responsibilities but they also have a lot of differences between them.

Firstly, the main objective is the same for both banks, "to keep under control the price stability". If this objective is normal for the ECB because of the fact that Euro zone member countries are industrially developed countries and not developing countries, for the Albanian economy this objective is contradictory because the Albanian economy in comparison with these countries is still distant. Albanian agriculture is underdeveloped. In this sector, only 41 thousand out of 350 thousand farmers were subsidized from the government in 2012. The agricultural sector has only 10 thousand tractors with tires. Consequently, the land in many districts of the country was cultivated by means of plow. There is a lack of selected and elite seeds, chemical fertilizers, pesticides and insecticides, as well. Farms in Albania are fragmented and too small, thus the introduction of mechanization is not promoted, agricultural cooperatives do not exist, etc. The agricultural processing sector is under development without any particular importance in the domestic production.

The industrial sector is not very developed, especially the light industry, namely the extraction and processing industry. Recently, a slight development was marked in the oil extraction sector from foreign companies. Development has been observed in the services and construction sectors. The tourism sector is under development, as well.

Foreign capital has been introduced and is mainly concentrated in the banking industry (13 commercial banks have private foreign-owned capital), in the mobile telephony where all the companies are foreign, in the facon industry sector where Greek and the Italian capital has been invested, in the construction material sector, cement sector etc. Due to foreign investments in Albania, circa 14 thousand people ${ }^{2}$ have been employed. In general, unemployment rate according to INSTAT amounts to $13.28 \%$, while according to Labor Unions, it exceeds $40 \%$ The income per capita is approx. 3.000 Euros. Inflation has been in steady quotas because generally it is imported; economic growth in the last 4 years has not exceeded an average of $3 \%$.

The import sector has been developed and a monopolization of imported goods has been observed.

In Albania there is a lack of the real estate market because there are over 100 thousand non-privatized objects, a lack of financial capital because there is no combination of the industrial capital with the financial capital, a lack of the capital secondary market (Stock market) etc.

Observing the economic situation in Albania, it results that the main problem is not the price control but the economic growth and the employment rate. Regardless of the official unemployment rate, actually unemployment exceeds $40 \%$ and economic growth, according to monetary indicators, has been so low that we can without doubt notice that the Albanian economy from the year 2009 onwards has been stagnant.

Secondly, the ECB further has two additional objectives in accordance with Article 2, to achieve and maintain a high employment rate and to provide for Eurozone member countries a sustainable non-inflationary economic growth.

The Bank of Albania is under the obligation to assist in the improvement of credit monetary conditions, in support of economic stability and development of the country. It is not a question of increase of employment or of a sustainable non-inflationary economic growth. The economic growth is not considered as an objective rather than as a consequence of the creation of the good monetary premises for economic growth.

Although the Eurozone consists of developed countries, it has, besides the inflation control, also the growth of the economy and of the employment rate as its objectives.

\section{Evaluation on the Permission of the Use of the Foreign Currency for the Purpose of Loans and Deposits}

\subsection{Deposits}

Besides ALL, the official currency, in Albania it is allowed to accept deposits and to grant loans in Euro and USD. At first glance, it seems as a normal action that allows free competition, but in fact, such an action has reduced the efficiency of monetary policies of the Central Bank. We analyze herein below the dynamics of deposits in ALL and in foreign currencies.

\footnotetext{
${ }^{2}$ Foreign investment. pdf. Report of FDI in Albania, 2010. Ministry of Finance
} 
Table No.1: Deposits Structure in millions ALL

\begin{tabular}{|c|c|c|c|c|c|c|c|c|c|c|c|}
\hline Name & $\begin{array}{c}\text { Deposits in } \\
\text { Total }\end{array}$ & $\begin{array}{c}\text { Deposits in } \\
\text { ALL }\end{array}$ & $\begin{array}{c}\text { \% of } \\
\text { total }\end{array}$ & $\begin{array}{c}\text { Deposits in } \\
\text { foreign } \\
\text { currency }\end{array}$ & $\begin{array}{c}\text { \% of } \\
\text { total }\end{array}$ & $\begin{array}{c}\text { Term } \\
\text { Deposits }\end{array}$ & $\begin{array}{c}\text { Term } \\
\text { Deposits in } \\
\text { ALL }\end{array}$ & $\begin{array}{c}\text { \% of } \\
\text { total }\end{array}$ & $\begin{array}{c}\text { Term Deposits in } \\
\text { foreign currency }\end{array}$ & $\begin{array}{c}\text { \% of } \\
\text { total }\end{array}$ & $\begin{array}{c}\text { Demand } \\
\text { Deposits }\end{array}$ \\
\hline 2008 & $\mathbf{6 1 9 , 8 8 6}$ & 359,187 & $\mathbf{5 7 . 9}$ & 260,699 & $\mathbf{4 2 . 1}$ & $\mathbf{4 6 7 , 7 2 8}$ & 272,142 & $\mathbf{5 8 . 1}$ & 195,586 & $\mathbf{4 1 . 9}$ & 152,158 \\
\hline 2009 & $\mathbf{6 6 2 , 4 2 5}$ & 369,137 & $\mathbf{5 5 . 7}$ & 293,288 & $\mathbf{4 4 . 3}$ & $\mathbf{5 1 1 , 5 4 0}$ & 293,675 & $\mathbf{5 7 , 4}$ & 217,865 & $\mathbf{4 2 , 6}$ & 150,885 \\
\hline 2010 & $\mathbf{7 8 5 , 2 2 4}$ & 409,458 & $\mathbf{5 2 . 1}$ & 375,766 & $\mathbf{4 7 . 9}$ & $\mathbf{6 1 7 , 3 8 4}$ & 329,090 & $\mathbf{5 3 , 3}$ & 288,294 & $\mathbf{4 6 , 7}$ & 167,840 \\
\hline 2011 & $\mathbf{8 7 5 , 2 2 6}$ & 452,080 & $\mathbf{5 1 . 6}$ & 423,146 & $\mathbf{4 8 . 4}$ & $\mathbf{7 0 6 , 4 9 8}$ & 370,105 & $\mathbf{5 2 , 3}$ & 336,393 & $\mathbf{4 7 , 7}$ & 168,728 \\
\hline 2012 & $\mathbf{9 3 0 , 7 0 0}$ & 476,872 & $\mathbf{5 1 . 2}$ & 453,830 & $\mathbf{4 8 . 7}$ & $\mathbf{7 5 2 , 9 5 4}$ & 388,330 & $\mathbf{5 1 . 5}$ & 364,624 & $\mathbf{4 8 . 4}$ & 177,746 \\
\hline
\end{tabular}

Source: Statistical Report. Bank of Albania. 02/2012 and 03/2013 Tirana

As results from the table data, we observe that:

Deposits in ALL compared to total deposits have decreased; foreign currency deposits compared to total deposits have been increased. In 2008 they amounted to $42.1 \%$ of total deposits, in 2012 they amounted to $48.7 \%$, deposits in ALL and in foreign currency tend to balance at $50 \%$ to $50 \%$. This is also observed in Picture No.1

Picture No.1: Dynamics of deposits for 2008-2012

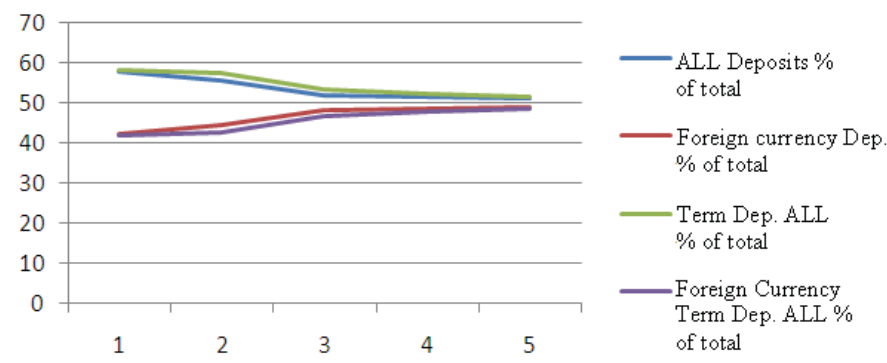

What are the causes to this situation in the dynamics and the structure of deposits?

First, because the interest rate of ALL deposits is higher than the interest rate of foreign currency deposits. Foreign currency deposits have increased because foreign currency loans have low interest rates.

Second, ALL has been annually devalued compared to the foreign currency. The largest devaluation was observed in 2009. In 2008 the Euro/ALL exchange rate amounted to 1/123.8 ALL and in 2009 amounted to 1/137.9 ALL. How is the correlation between the deposit growth rate and the growth rate of GDP?

This is answered by the data of table No. 2 .

Table No. 2: The rate of change for Deposits and GDP (2009-2012)

\begin{tabular}{|l|c|c|c|c|c|}
\hline & 2008 & 2009 & 2010 & 2011 & 2012 \\
\hline \% of deposits growth & $\mathrm{X}$ & 6.8 & 18.5 & 11.4 & 6.3 \\
\hline \% of GDP growth & 7.7 & 3.3 & 3.5 & 3.4 & 1.8 \\
\hline
\end{tabular}

Based on the data, it is clearly noticed that GDP growth rate does not correspond to the deposits growth rate. It varies from 2 to 6 times in favor of the deposits. The lack of their efficiency is associated with the destination of their usage. How many are used for the development of the economy and how many are used for the purchase of government securities? How many loans are provided to productive sectors and how many are provided to non-manufacturing sectors? 
Table No.3: Structure of loans in million ALL

\begin{tabular}{|c|c|c|c|c|c|}
\hline Name & Total loan & Loan in All & \% of total & Loan in foreign currency & \% of total \\
\hline 2008 & 396,264 & 114,051 & $\mathbf{2 8 . 8}$ & 282,212 & $\mathbf{7 1 . 2}$ \\
\hline 2009 & 440,397 & 140,479 & 31.9 & 299,918 & 68.1 \\
\hline 2010 & 483,129 & 157,197 & 32.5 & 325,932 & 67.5 \\
\hline 2011 & 541,899 & 188,779 & 34.8 & 353,120 & 65.2 \\
\hline 2012 & 554,732 & 215,122 & $\mathbf{3 8 . 7}$ & 339,609 & 61.2 \\
\hline
\end{tabular}

Source: Statistical Report. Bank of Albania. 02/2012 and 03/2013. Tirana

As results from the table above, we observe that:

There has been an increase of the loan in total, since y. 2008 until y. 2012 it has increased by $38.7 \%$. The ratio of the total loan to the GDP is low and constitutes less than $45 \%$ thereof. The internal structure of the loan has changed. The loan in ALL has increased from $28.8 \%$ to $38.7 \%$, whereas the loan in foreign currency has decreased from $71.2 \%$ to 61.2\%. In 2012 the loan in foreign currency was 57.8\% higher than the loan in ALL. In later years it has been over 100\%. Amongst loans lent by second-tier banks it is the loan in foreign currency that prevails compared to the loan in ALL. This is positive because the European economy uses the same currency, but in the same time it is also negative because its basic rate does not depend on the basic rate determinable by the Central Bank of Albania. Such loan is generally used in the investment area and not for purposes of broad consumption goods. It is due to this fact that the loan in foreign currency affects the rates of the Albanian economic growth more than the loan in ALL.

\section{Evaluation of the Use of Flexible Foreign Exchange Rates}

After 20 years of transition, the Albanian economy has taken on characteristics of a small open economy regardless of the fact that its exports-imports in relation to the GDP do not exceed $50 \%(505.2 / 1282 * 100=39.4 \%)$ and the interest rates have not consequentially followed the interest rates of the world. It is a developing and growing economy, undeveloped in industry, agriculture, services, transport, tourism, etc. Albania is a country that consumes, imports basic food products at a ratio of $1 / 6$ at a time when the general ratio of export-import $1 / 2.3$. The basic ratio with the ratio of import-export is $1 /$ 2.3(3,524 ml imports/1,525 ml exports, y. 2012). In Albania there are no consolidated markets, such as the land market, housing market, the secondary market of securities, etc. There is lack of financial capital as a combination of industrial and bank capital. There are no economic phenomena found in developed countries, therefore there are no bankbusiness-stock market transmission effects. In the current circumstances of the economy, not everything may be copied from the West and be applied without any change, as has occurred in many areas.

Below we will analyze how fiscal and monetary policies affect a country like Albania that applies flexible foreign exchange rates.

\subsection{Fiscal Policy}

Suppose that the Albanian government will reduce the tax rates or that it will increase government purchases. Would such an expansionist policy result in increase of income, and, in general, in improvement of macroeconomic indicators? If the Albanian economy were a closed economy, such a policy would increase the income. In a small open economy, with a flexible foreign exchange rate, the fiscal expansion causes the income to remain at the same level. Why has not income increased in the case of the Albanian economy? This is answered by the IS-LM ${ }^{3}$ curbs. There are two cases of fiscal expansion.

In the first case, when the government operates in ALL. In this case it can reduce the tax rate or it can increase government purchases. As a result, the amount of money in circulation does not change, and, therefore there will be no change in the resulting indicators both in income and inflation. There may be a temporary increase of the aggregate

\footnotetext{
${ }^{3}$ The IS-LM curbs are curbs of the equilibrium model and take into consideration the involvement of monetary policies. The IS (Investment-Savings) curb deviates from the simple Keynes' model, while the LM (Money Demand and Supply) curb deviates from the monetary market model (the Mundell-Fleming model).
} 
demand but with no effect on the income level.

In the second case, if the government receives loans in foreign currency from foreign financing entities by means of securities or loans, then there will temporary reactions in the monetary market.

The expansionist policy would increase government expenses. Government expenses would increase the aggregate demand and the increase of the aggregate demand would move the IS curb on the upper right, as shown in the table No. 2. The Euro exchange rate will be devalued, while the income level would temporarily increase due to the exchange of the foreign currency to ALL. But its exportation and the decrease of the foreign exchange rate will bring it back again to the previous position. Therefore the growth tendency is eliminated by moving from $c \rightarrow a \rightarrow b$ and ends in the starting point of income at I $\mathrm{S}_{1}$.

In a closed economy, when there is an increase of income, there is also an increase of interest rates because the income increase will result in increase of the money demand. Such is not possible in a small open economy because the interest rate would immediately increase above the interest rate of the world and the capital would flow abroad. This is not the Albanian case, though, because the interest rate of the ALL has always been higher than the interest rates of the Euro and the USD. The ALL rate has never attempted to follow their rates. Under such circumstances, an increase of money demand would be normally expected. But what has actually happened? The basic interest rate of ALL has decreased slowly.

Table No. 4: Correlation between the basic interest rates and the interest rates for loans and deposits

\begin{tabular}{|c|c|c|c|c|}
\hline & $\begin{array}{c}\text { Deposits. 12-month4- } \\
\text { interest rate }\end{array}$ & $\begin{array}{c}\text { Loans. 12 month- } \\
\text { interest rate }\end{array}$ & $\begin{array}{c}\text { Treasury bonds. 12- } \\
\text { month-interest rate }\end{array}$ & $\begin{array}{c}\text { Interest of one-week re-purchase } \\
\text { agreement (REPO5) }\end{array}$ \\
\hline 2008 & 6.93 & 11.75 & 8.56 & 6.25 \\
\hline 2009 & 6.78 & 12.46 & 9.14 & 5.25 \\
\hline 2010 & 6.4 & 11.29 & 7.09 & 5.00 \\
\hline 2011 & 5.87 & 11.17 & 6.95 & 4.75 \\
\hline 2012 & 5.38 & 10.28 & 6.37 & 4.00 \\
\hline
\end{tabular}

Source: Bank of Albania. Overall macroeconomic indicators. Statistical Report 03/2013.

This reduction has not been accompanied by the expected increase of aggregate indicators, but, on the contrary, this phenomenon has, as was explained above, occurred only for $\mathrm{M}_{3}$ and $\mathrm{M}_{2}$, while the other aggregate indicators have either been reduced, or have remained unchanged. In this way, in our case, even if we consider the Albanian economy as a closed economy, the expected phenomenon has not occurred. The expected supply of the foreign currency in Albania has not occurred due to the interest rate, but due to other reasons.

- The foreign currency supply depends on the supply from exports, from the supply of Albanian emigrants working abroad, from foreign investments, the sale of state-owned land, from the loans the government has received, etc.

- The foreign currency demand in Albania depends on imports, sales amount of housing, land and other immovable properties, from investments such as deposits, securities of financial entities out of the Albanian territory, from the demand for work and vacation movements, etc.

In light of the above, in terms of foreign exchange flow and supply deriving from foreign exchange rates, these are dependable to the rates of the Euro and of the USD freely circulating in Albania, the same as the ALL. Taking into consideration that the interest rate of loans in ALL is high, many few persons and entities receive loans in ALL, everyone directs themselves towards foreign currencies. Not only do foreign currencies constitute the main part (at a 60/40 ratio) of loans, but they are ever more leaving Albania in the forms of deposits in banks outside Albania or in the form of foreign financial activities' purchase.

\footnotetext{
${ }^{4}$ Annual weighted average rate of new 12-month deposits and loans in ALL for the banking system.

${ }^{5}$ The data refers to the rate at the end of the period.
} 
Picture No. 2: A fiscal expansion under a variable foreign exchange rate

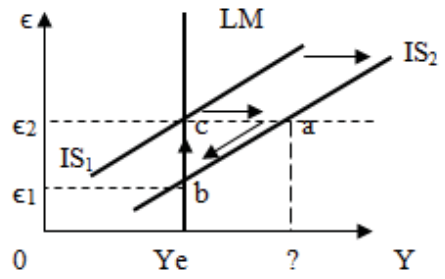

The evaluation of the foreign exchange rate will make the domestic goods relatively more expensive than the foreign and this will reduce net exports. Reduction of net exports will pose pressure on the effect expansionist policies have over the income.

Why is the reduction of net exports an important factor for making the fiscal policy totally ineffective for purposes of influencing the income? In both closed and open types of economy the real money demand and supply are balanced.

In the Albanian economy, i(the internal interest rate) has been ineffectual for the change of i*(the interest rate of the world), therefore this equation may be satisfied only at a given level of income. This level of income may not be changed even when the fiscal policy changes. So, when the government increases expenses or reduces taxes, as has happened in Albania, the assessed foreign exchange rate and the reduction of net exports are exactly at the same amount required for posing pressure totally on the normal effect of the expansionist policy over the income.

Table No. 5: Fiscal indicators of the government

Fiscal statistics of the government

\begin{tabular}{|c|c|c|c|}
\hline Years & Income & Expenses & Deficit(-) \\
\hline 2007 & 251,555 & 285,674 & 34,119 \\
\hline 2008 & 291,238 & 351,492 & 60,254 \\
\hline 2009 & 299,597 & 379,602 & 80,005 \\
\hline 2010 & 324,721 & 362,752 & 38,031 \\
\hline 2011 & 330,475 & 376,352 & 45,877 \\
\hline 2012 & 330,383 & 376,239 & 45,856 \\
\hline
\end{tabular}

Source. Bank of Albania. Statistical Report. November 2009. Statistical Report. April 2010. Monthly Statistical Report. 10/2011. Statistical Report. 10/2012. Statistical Report 03/2013.Tirana. Bank of Albania.

Let's explain it. The increase of government expenses will normally move the IS curb on the right. This move will cause devaluation of the domestic currency, the ALL, due to the increase of the cash flow. Such devaluation would ignite the increase of net exports and, as a result, the increase of income. It is not the case in the Albanian economy, actually. Why? The answer is simple. It is because the government's expansionist policies, as shown in table No. 5, have not affected the increase of the amount of money in circulation due to the fact that monetary aggregate indicators have not been increased. This means that such money has been transferred from the business to the government in various forms, without adding to it the amount of the money in circulation. Therefore, the lack of increase of money in circulation results in no change in foreign exchange rates. It is mostly the change of the amount of money in circulation rather than of the ALL that affects the foreign exchange rates. This phenomenon has occurred during recent years.

Analyzing foreign exchange rates on a monthly basis for the years 2008-2012, it is evidenced that the ALL is valued in periods when emigrants visit Albania, such as during Christmas, New Year or during summer holidays. Data on foreign exchange rates per month are shown in the Table No. 6 . 
Table No. 6: Euro foreign exchange rates per month (ALL/Euro)

Euro average foreign exchange rates

\begin{tabular}{|c|c|c|c|c|}
\hline & Year 2008 & Year 2009 & Year 2010 & Year 2011 \\
\hline January & 122.61 & 125.18 & 138.28 & 138.65 \\
\hline February & 123.69 & 128.79 & 138.80 & 139.59 \\
\hline March & 124.59 & 130.67 & 139.20 & 140.14 \\
\hline April & 122.68 & 130.46 & 138.36 & 141.48 \\
\hline May & 122.08 & 132.05 & 136.72 & 141.8 \\
\hline June & 122.03 & 131.16 & 136.65 & 141.97 \\
\hline July & 121.87 & 129.66 & 136.11 & 139.92 \\
\hline August & 121.44 & 131.01 & 136.24 & 139.85 \\
\hline September & 123.05 & 133.94 & 137.05 & 140.49 \\
\hline October & 123.13 & 136.90 & 138.39 & 140.81 \\
\hline November & 123.29 & 137.70 & 138.82 & 140.97 \\
\hline December & 123.18 & 137.17 & 138.81 & 138.3 \\
\hline
\end{tabular}

Source. Bank of Albania. Statistical Report. November 2009. Statistical Report. April 2010. Monthly Statistical Report. 10/2011. Statistical Report. 10/2012. Tirana. Bank of Albania.

Based on the abovementioned data, the relevant graphics referring to months and years, may be drawn up.

Picture No. 3: Curbs of Euro foreign exchange rates

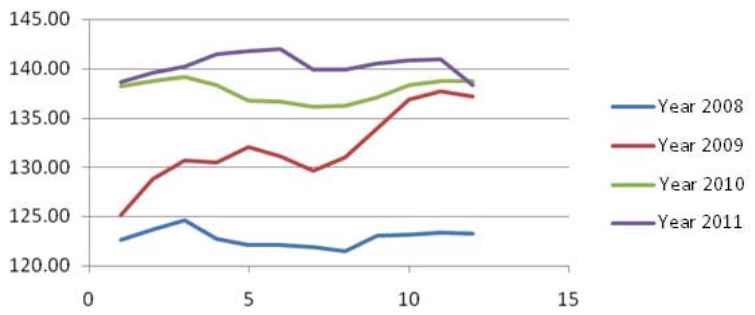

As results from the table and the graphics, it is clear that the foreign exchange rates vary depending on emigrants' homecoming. Euro foreign exchange rates are low during January-July-August and December. This is due to the fact that these months coincide with emigrants' homecoming. The contrary has occurred during the other months, when there is a valuation of the Euro.

We can compare in the same way the correlation between the foreign exchange rates, the amount of money out of banks and the monetary basis. The above data are an average for the years 2008-2012.

Table No. 7: Correlation of the BM and the PJB with the foreign exchange rates ${ }^{6}$

\begin{tabular}{|c|c|c|c|}
\hline Months & BM(average) million ALL & PJB, million ALL & EURO exchange rate (average) ALL/Euro \\
\hline January & $\mathbf{2 5 9 , 7 6 5 . 8 0}$ & $182,324.4$ & 131.180 \\
\hline February & $\mathbf{2 5 9 , 0 3 4 . 4 0}$ & $182,648.2$ & 132.718 \\
\hline March & $\mathbf{2 5 7 , 6 8 6 . 7 6}$ & $182,131.8$ & 133.651 \\
\hline April & $\mathbf{2 5 7 , 8 6 9 . 3 2}$ & $182,494.6$ & 133.245 \\
\hline May & $\mathbf{2 5 8 , 3 1 4 . 5 9}$ & $182,135.3$ & 133.164 \\
\hline June & $\mathbf{2 6 1 , 2 4 9 . 8 4}$ & $184,129.7$ & 132.954 \\
\hline July & $\mathbf{2 6 4 , 3 8 2 . 1 2}$ & $186,987.8$ & 131.890 \\
\hline August & $\mathbf{2 6 4 , 9 2 7 . 5 6}$ & $186,665.5$ & 132.134 \\
\hline September & $\mathbf{2 6 5 , 8 7 0 . 8 1}$ & $183,850.2$ & 133.633 \\
\hline
\end{tabular}

6. The data are the average of the years 2008-2012. 


\begin{tabular}{|c|c|c|c|} 
October & $\mathbf{2 6 8 , 4 8 5 . 4 2}$ & $185,864.2$ & 134.808 \\
\hline November & $\mathbf{2 6 9 , 9 1 1 . 5 1}$ & $187,658.0$ & 135.195 \\
\hline December & $\mathbf{2 8 2 , 4 5 7 . 5 5}$ & $198,710.6$ & 134.365 \\
\hline
\end{tabular}

Source: Bank of Albania. Statistical Report. November 2009. Statistical Report. April 2010. Monthly Statistical Report. 10/2011. Statistical Report. 10/2012. Statistical Report 03/2013. Tirana. Bank of Albania.

Based on the above data, it results that the correlation between them is very weak. This indicates that the changes of the monetary aggregate indicators based on ALL lack the relevant effect to the foreign exchange rates. Thus, the policies of the Central Bank on foreign exchange rates do not have any effect on the economic growth.

Picture No. 4: Dynamics of BM, PJB and Euro on a monthly basis during 2008-2011(average)

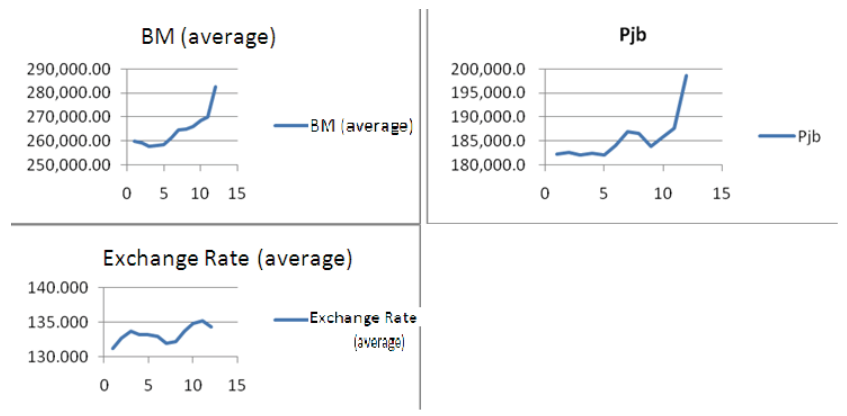

Based also on the above graphics it is clear that the correlation between the monetary aggregate indicators based on $\mathrm{ALL}$ and the Euro exchange rate is weak.

\subsection{Monetary policy}

Now we assume that the Central Bank will increase the money supply. When we talk about money supply we only mean the aggregate indicators depending from the ALL's position as a Currency Outside Bank, Monetary Base, M1 and M2. Assuming fixed price level, an increase in the money supply through significant reduction of the base interest rate (REPO) will increase the real balances. An increase in real balances will shift LM curve to the right as in the picture No.5. Therefore, increasing the money supply will increase the incomes and exchange rate and constantly the local currency will be devalued and income will increase.

Monetary policy affects the revenues in a small open economy, while in a closed economy does not influence. In such economy, the monetary transmission mechanism is different. In a closed economy, an increase in the money supply increases the expenses because it reduces the interest rate and stimulates investment. Normally, in a small open economy, the domestic interest rate is fixed by the world interest rate. In the case of the Albanian economy, the base rate has not followed the pace of change in the interest rates in the world. Further, the rates of deposits and loans in ALL have not followed the change of the basic interest rate. They have reflected Commercial Banks' strategies for the medium term (see table 4) as regards interest rate loans and deposits in Euros, they have accompanied the change of rate of the Euro to change its function from the European Central Bank. The same phenomenon happened with USD interest rates. Banks have followed the interest rate position that has been defined by the American Fed. Changes in the basic interest rate (REPO) of ALL have not received much consideration in the amount of loans because they have granted for sure their field of investment that is government securities. Majority in deposits in ALL, about $60 \%$ of them is invested in buying securities from the Albanian government, while only about $40 \%$ of them for credit. 
Picture no. 5: A monetary expansion of the variable exchange rate.

An increase in the money supply shifts LM curve to the right, the exchange rate decreases and increases revenue.

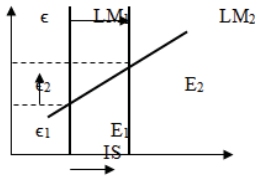

$$
\begin{array}{llll}
0 & \mathrm{Y}_{1} & \mathrm{Y}_{2} & \mathrm{Y}
\end{array}
$$

This effect of economy growth as a result of currency in circulation, the growth of monetary aggregate indicators has not been evident. The reason is because these aggregates are not increased, so the Central Bank has had little impact in this area. Decrease in the exchange rate, domestic currency devaluations make domestic goods relatively less expensive than foreign goods and stimulate exports.

\section{Evaluation of the Currency Monopolization in the Hands of the Central Bank}

If currencies (Euro and USD) would be monopoly of the Central Bank, then the problems would be different because economic entities would turn to the Central Bank. All the currency will be hoarded in the bank and will not be utilized by the banks of the second level except for the effects of transactions with entities within or outside the country. So if the currency will be monopolized the construction sector will not require to sell apartments in Euro but selling them in ALL and the actions to pass through the bank. This would make millions of Euros not to go to this destination but contrary to gather in a particular hand which will merchant that for the Albanian economy interest with fixed exchange rates. The probability of halting the transactions in foreign currency is shown in the Table no. 8.

Table no. 8: Individual + Business loans distribution by currencies for y. 2012 in millions ALL

\begin{tabular}{|c|c|c|c|c|c|c|c|c|c|c|}
\hline & $\begin{array}{c}\text { Total } \\
\text { Loans }\end{array}$ & $\begin{array}{c}\text { Short-term } \\
\text { Goods }\end{array}$ & $\begin{array}{c}\% \text { of } \\
\text { total }\end{array}$ & $\begin{array}{c}\text { Long terms } \\
\text { Goods }\end{array}$ & $\begin{array}{c}\% \text { of } \\
\text { total }\end{array}$ & Real estate & $\begin{array}{c}\% \text { of } \\
\text { total }\end{array}$ & Overdraft & $\begin{array}{c}\% \text { off } \\
\text { total }\end{array}$ & $\begin{array}{c}\text { Exercise of } \\
\text { Activity }\end{array}$ \\
\hline ALL & 206,397 & 59,784 & $\mathbf{2 9 . 0}$ & 27,587 & 13.4 & 66,573 & $\mathbf{3 2 . 3}$ & 48,474 & $\mathbf{2 3 . 5}$ & 3,978 \\
\hline Currency & 337,041 & 36,077 & 10.7 & 69,940 & $\mathbf{2 0 . 8}$ & 148,186 & 44.0 & 80,016 & 23.7 & 2,817 \\
\hline Amount & 543,438 & 95,861 & 17.6 & 97,527 & $\mathbf{1 7 . 9}$ & 214,759 & 39.5 & 128,490 & $\mathbf{2 3 . 6}$ & 6,795 \\
\hline
\end{tabular}

Source: Banka of Albania. Statistical Report 03/2013.

From the above table, we note that:

The main part of the foreign currency loan, $67 \%$, is allocated to real estate and overdrafts. This item includes loans for housing, for land acquisition, construction, manufacturing, etc. It is important to note here that 67 billion ALL are foreign exchange costs by individuals for purchase of real estate and 80.7 billion ALL are business expenses. They cost more than 1 billion Euros. Note that these foreign currency amounts cannot be used to purchase real estate within the country but to purchase machinery and equipment abroad for economic development, instead. This is one side, because on the other hand the demand for foreign currency assets for real estate, for overdraft or short-term consumption goods has artificially increased the demand for currency devaluation affecting the ALL.

For long-term goods only $21 \%$ has been spent. In this item we include credits for machinery and equipment raw material etc.

Picture No. 6 Loan Distribution

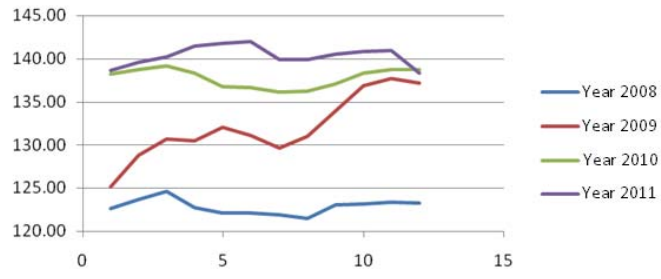




\section{Are the Monetary Policies of the Bank of Albania Effective to the Inflation Control?}

In order to explain if the monetary policies of the Bank of Albania are effective to control the inflation, it is important to explain the factors that determine the rate of inflation in the Albanian economy.

1. The Albanian economy is a small open one. Normally in such economies, where the incomes do not correspond with the expenses, the applicable interest rate depends on the interest rate applicable in the other countries in the world. That means that the monetary policies of the countries like Albania, are dependent on the monetary policies of central banks of other countries with large open economy. In particular, the Albania monetary policy depends on the monetary policy of the European Central Bank. After the 2008, the year of the global recession commencement, the Bank of Albania should have adopted to the recession of other European countries and not to be standing opinion that this economy will not be affected by recession.

Following the change of the base interest rate of the European Central Bank, the Bank of Albania should have reduced the interest rate at a high rate, in order to affect the interest rate of the loans issued by the Commercial Banks. Such a reduction should have been of an important rate, because its competitors, using Euros and USD, undertook spectacular action, reach 0 , by doing so. When, they were reaching 0 , the base interest rate in Albania was 6.25\% (2009). Through an expansionist policy, the Bank of Albania should have stimulated the growth of aggregate demand, which would have affected the growth of supply. The real effect of this action would be the real economic growth and appreciation of the role of the ALL in this growth.

In case the Bank of Albania applied an expansionist policy, there would have not been an increase of the prices, because the circulation of goods and services is partially undertaken in Euro and USD. In this respect there is a lack of circulation in ALL.

2. The local production. Following the technical arguments listed above, we may be reserved with regard to the local production and its impact in the inflation rate. Thus, no good is manufactured at a quantity exceeding half of our total demand needs. If such were to happen, then the local price would affect the import price. Such phenomenon happens in short periods only in the agricultural sector, in June, July and August.

3. Export-import ratio is $1 / 2.6$. The majority of the basket goods, under which the consumer price index (CPI) is estimated, is imported. Their prices are determined outside the Albania and are imposed to the locally produced goods.

4. Exchange rate of the ALL in Albania is flexible, although occasionally the Central Bank intervenes in the market by buying or selling foreign currency. They affect the price level in the country and in the development of country's economy

5. Export is not the main flow of foreign currency in the Albanian economy. The foreign currency is ensured from the exported workforce of the Albanian emigrants working in other countries, as well as, foreign investment in Albania and informal sector etc.

6. Political and social stability of the countries with which Albania has trade relations such as Italy, Greece, Turkey, Kosovo, etc. Italy and Greece are not yet out of recession and depression where are absorbed. Kosovo, Macedonia and the the countries in the region do not have severe political problems but, they are facing internal stability problems.

In light 0 the above factors, affecting the inflation rate, our question is which are the main reasons that the Albanian Central Bank may not control the inflation.

First, three currencies circulate in Albania without any limitation, as the ALL. To date in Albania, two other foreign currencies circulate equally as the Albanian Lek, the Euro and the USD. Considering the ratios of total deposits and loans, it is evident that the ALL is offset in circulation. Most of the deposits are in ALL, due to high interest rate, while most of the loans are in foreign currency, because the interest rate for loans in Euros and USD are much lower than those in ALL. The position of the Central Bank regarding the situation after the 2008 is almost neutral considering the inflation indicator, which was low in Albanian these last years, not due to the Central Bank, but rather due to the global recession and financial crises. The Central Bank has reduced the base interest (REPO) at a symbolic level, without following actions of the European Central Bank and other central banks of countries outside the EU. A part of these banks reduced the base interest rate at 0.5\%, when the Albanian Central Bank implemented such action only in 2012. In particular, in 2008 the base interest rate was $6.25 \%$, in 2009 was 5.25\%, in 2010 was 5\%, in 2011was 4.75\% and today in 2013 the base interest rate is 3.75\%. This attitude of the Albanian Central Bank has negatively affected the increase of the circulation of the ALL in investments, stimulating its channeling in the budget through treasury bonds. 
Second, there is no state-owned second-tier bank in Albania. Considering that there is no state-owned bank, and considering that the Euro and the USD are freely used for deposits and loans, it is very difficult for the Albanian Central Bank to influence the currency market or the monetary aggregate indicators. Today, the banking system consists only in banks with foreign private capital and no state-owned bank is present. Due to such situation, an oligopoly market structure is established, where "Raiffeisen Bank", an entirely foreign-owned entity is the leading bank.

Third, the dependence from the parent banks of the banks operating in Albania. The current crisis among others revealed the link between the presence of foreign banks and monetary policy efficiency. In case the foreign banks are important financial actors in the internal economy and in case their activity as lender and borrower is affected by economic conditions of the mother country, rather than the hosting country conditions, the efficiency of monetary policy implementation is weak. The Central Bank implemented a series of measures in 2008, but their effect was not the expected ones, regardless of the situation is evaluated under different angles. On 14 December 2010, the governor of the Central Bank declared that: "The lending activity slowed sharply, the exchange rate started to depreciate, and the expectations in terms of economical growth and inflation decreased. Meanwhile, deposit withdrawals continued and the liquidity problems went deeper. Prior to the crisis, the Bank of Albania was concerned about the potential financial threats accumulated during the fast financial intermediation years.

\section{General Conclusions}

- The Bank of Albania has an incomplete objective in relation to the objectives of the $E C B$, therefore the Bank of Albania must take as its objectives the two objectives of the ECB that are related to the primary objective.

- Deposits are growing but at higher rates than the level of economic growth. Their structure has changed in favor of the foreing currency due to distrust for the ALL because of its continuous devaluation.

- Foreign currency loans are larger than ALL loans. Foreign currency loans are generally used to purchase economic factors and not consumer goods. Foreign currency loans have interest rates lower than ALL loans. The interest rate does not depend on foreign currency loans by the Bank of Albania and the European Central Bank. Both Euro and USD deposits and loans have reduced the circulation of ALL, its effect on economic growth and have impacted negatively on their distribution between branches and sectors.

- Expansionist government policies have not increased the quantity of money in circulation as monetary agregates are not increased. This means that from the bussines this money has been transferred to the government in various forms without increasing the quantity of money in circulation. Lack of increase of the quantity of money in circulation results in no change in exhange rates. The change of amount of the foreign currency rather than of the ALL has the highest impact on exchange rates. This phenomenon has been proved during the last four years.

- Any expansionist policy of the government not associated with increased monetary aggregates is not effective in increasing income. It realizes the transer of money by one to another and temporarily increases aggregate demand without having any impact on exchange rates.

- When the government takes loans from foreign economic entities, there is a growth of the foreign currency in circulation and the ALL is valued. Its evaluation poses pressure to the income in order to pass to the initial position without change.

- In terms of a small open economy like the Albanian economy, monetary policy affects the income of altering the exchange rate better than interest rate. In this way, monetary policies have full effect on economic growth. This has not happened in the Albanian economy because other currencies are the Euro and the USD that eliminate this effect. The reasons are interest rates and flexible exchange rates.

- If the Bank of Albania applied an expansionist policy, there would be no increase in the level of the prices because a part of the flow of goods and services are realized in Euro and USD. In this addition, no increase in the price level is proved by lack of the ALL.

\section{References}

Prof. A. Angjeli, Prof. A.Kadriu, Doc. A.Naqellari. Makroekonomiks. First edition, Publisher: International University of Struga, Macedonia, Mediterranean University of Albania. Albania in 2010.

N.Gregori Mankiw. Macroeconomics, Fourth Edition, USA 2000.

Abel/Bernanke. Macroeconomics, Third Edition 1998. USA 
Figures in Albania. 2010. INSTAT

Monetary Policy Report for the third quarter of 2012. Bank of Albania

"The global recession and its impact on the Albanian economy ". Monograph. Alqi Naqellari, Robert Maliqi \& Almarin Naqellari Tiranë 2012.

International Shientific Conference. Albania and the Crisis: What's next? Revisiting the growth model. 15-16 december 2012. "Effect of monetary policy on the economy during the global recession from 2008 to 2011". Alqi Naqellari \&Terida Mëhilli

Financial Stability Report on The First 6 months of the year 2011. Bank of Albania 2011

Statistical Report. November 2009. Tirana. Bank of Albania.

Statistical Report. April 2010. Tirana. Bank of Albania.

Statistical Report. April 2011. Tirana. Bank of Albania.

Monthly Statistical Report. 10/2011. Bank of Albania 2011.

Statistical Report. April 2012. Tirana. Bank of Albania.

Statistical Report. 03/2013. Tirana. Bank of Albania.

Statistical Report. 02/2012. Tirana. Bank of Albania.

Statistical Report. 10/2012. Tirana. Bank of Albania.

Statistical Yearbook of Albania 1991. Ministry of Economy. Department of Statistics

Statistical Yearbook. Ministry of Agriculture 2009. MBUK. Statistical Yearbook 1976.

Figures in Albania.2010. INSTAT

Alqi Naqellari. Model economic and agricultural development challenges. Albanian Journal. 29.04.2010

The statisticsof Foreing Trada are taken from http://ŵŵw. instat.gov.al

Naqellari A. 2004, Principles of Economics, Tirana Dardania (ed)

Mancellari A., Haderi S., Kule DH., \& Qirici S.2002, Principles of Economics, Tirana, Pegi (ed)

Antonelli G.,Cainelli G., De Liso N., Leoncini R. \& Montresor S. 2007, Economia,Torino G. Giappichelli (ed)

Mehilli T., Xhafa K., Naqellari A., Demo E., "The Influence of Financial System in Albanian Economy" Book of Proceedings, $2^{\circ}$ International Conference on Human and Social Sciences ICHSS 2012 - March 23-24, 2012, Tirana, Albania Volume 2, pg. 9 http://Ŵŵî.mcser.org/images/stories/4_conferences/ICHSS_2012/volume\%202.pdf

The Fifth International Scientific Conference "Investment in the function of economic development and integration processes". Ulcinj april 2013. "Financial system and its impact on the Albanian economy". Alqi Naqellari \&Guximtar Rushani.

Naqellari.A." The negative Consequences of the Restructuring of the Albanian Banking System since the 90-s" Pg. 435-447. Mediterranean Journal of Social Sciences. Vol. 4,No.6,July 2013. 